\title{
Geomorphological Variables that Determine the Magnitude of Stream Floods in Wadi Al-Hasa - South Jordan
}

\author{
Ali Hamdi Abu- Salim ${ }^{1}$ \\ ${ }^{1}$ Department of Geography, AL-Hussein Bin Talal University, Ma'an, Jordan \\ Correspondence: Ali Hamdi Abu- Salim, Department of Geography, AL-Hussein Bin Talal University, Ma'an, \\ postal code: 71111, P.O. Box (20), Jordan. Tel: 962-772-138-367. E-mail: alihamdaaaa@yahoo.com
}

Received: August 19, 2014 Accepted: September 3, 2014 Online Published: October 24, 2014

doi:10.5539/jgg.v6n4p42

URL: http://dx.doi.org/10.5539/jgg.v6n4p42

\begin{abstract}
The study aims to analyze the geomorphological variables that determine the magnitude of stream floods in Wadi Al-Hasa through the analysis of the characteristics of rainfall; the shape and areal dimensions of the basin; the topography of the surface; the gradient of the Valley; the characteristics of water discharge network; and the morphology and capacity of the channel. To achieve the objectives of the study, the Analytical Approach was adopted when examining stream floods. This approach is based on the analysis of the climatic information and the hydrological data available on stream floods in Wadi Al-Hasa; and the analysis of the morphometric, hydrological and vegetation measurements that have been extracted from the topographic maps, aerial photographs and field work.

The study found several results including: the increasing likelihood of frequent flooding in the sub-reaches of Wadi Al-Hasa with the increase in their stream orders, as a result of the increase in the amount of water discharge. Moreover, the results of the statistical analysis of the stepwise regression showed the importance of the following variables: (the stream order, the gradient, the width of the river channel and vegetation) in explaining the variation in the volume of the water discharge of the river tributaries in the basin, as these variables interpreted about (53\%) of the total variation. The study also found that there are three areas with increased likelihood of flooding in the basin, namely: the estuaries of the eastern tributaries in Qa' Al-Jinz area; the areas where western tributaries meet with higher stream orders; and the estuary area of the mainstream of Valley.
\end{abstract}

Keywords: Wadi AL- Hasa, geomorphological variables, upstream area, drainage density, bifurcation rate

\section{Introduction}

Stream Floods in arid lands are considered to be natural hazards that threaten the stability of their ecosystems and their ability to sustain its natural resources as a result of the devastating effects these floods have on the ecosystems of river basins and their land resources, especially soil, vegetation and water resources. Stream floods in arid valleys are classified as swift natural hazards that have a short lifetime which form and fade quickly; as their permanence is associated with incessant rainfall on watershed areas, and the flow of runoff water in upper streams. (Leopold et al., 1964; Costa, 1987; Harun, 1987; Baker and Pickup, 1987; Jennifer and Brian, 2002; House et al., 2002; Sullivan et al., 2004; England et al., 2010; Foulds et al., 2014). Most recent studies in the field of Environmental Sciences and Geography, dealing with stream floods, have focused on the role of human activities in increasing their magnitude in the absence of proper land-use planning. These studies also addressed the flood devastating impacts, and flood risk management in order to mitigate their negative effects on land resources. Moreover, these studies showed that the deterioration of the ecosystem of the river basins increases the overflow of stream floods through its impact on the drainage system in those basins (Patterson, 1964; Schick, 1971; Patton et al., 1979; Smith, 1989; Jarrett, 1999; Levish et al., 2003; Minea and Zhaharria, 2011; Sami et al., 2013). Specialists in the field of environment have put a set of measures that limit these dangers (Brammer, 1990; Woube, 1999; Moussa et al., 2002). Nevertheless, they did not tackle the processes of stream flooding; the geomorphological variables that define the magnitude of stream floods in arid areas; and their compatibility with those measures, in a comprehensive and detailed manner. This study came to fill in the gap overlooked by the previous studies in examining the geomorphological variables that determine the magnitude of stream floods and their development. Hence, this study will contribute, at the local level, in 
developing a comprehensive strategy to address the problem of flooding in arid valleys in the south of Jordan, taking into account the geomorphological variables that increase the risk of flooding in arid environments.

\section{Study Objectives}

The study aims at accomplishing the following targets:

1) Examining the basin environment of Wadi Al-Hasa and analyzing its impact on increasing the magnitude and continuity of the floods.

2) Analyzing the geomorphological variables that determine the magnitude of water flooding in the Valley through the analysis of their direct impact on the water discharge flowing in the streams of the water network of the Valley. Among the most important of these variables are: rainfall, the basin area and its shape, the surface topography, the morphology of the river channel and its capacity.

3) Measuring the size of the water discharge in the river tributaries of different orders, and linking the results of these measurements with the probability of stream floods, in order to identify the areas that are exposed to the risk of flooding in Wadi Al-Hasa.

4) Classifying the areas of flooding risks in Wadi Al-Hasa according to the possibility of the recurrence of floods into three levels: normal, medium, and high.

\section{Methodology}

In order to achieve the objectives of the research, the study adopted the Analytical Approach in dealing with the issue of stream floods in Wadi Al-Hasa. This approach focused on the analysis of three major dimensions. The first dimension is represented in the analysis of the basin environment of the Valley and its indirect impact on increasing the magnitude of the flood. The second dimension is represented in the analysis of climatic information and hydrological data available from the floods that have occurred in the Valley during the period (1960 - 2013). The third dimension is represented in the analysis of the morphometric, hydrological, and plant measurements that have been drawn from field work, topographic maps $(1-50,000)$ in 2008 , and aerial photos (1-25000) for the year 2010.

The results of measurements have been processed using Stepwise Regression Model in order to identify some of the morphometric and hydrological variables that determine the volume of water discharge of the river tributaries of different orders; where a matrix of morphometric and hydrological variables of (140) river tributaries, was subjected to statistical analysis. Among the most important of these variables were: the volume of water discharge; the speed of river flow; the width of the channel; the length of the channel; the gradient degree of the river; the length of the river tributary and its discharge density; and stream order. The matrix also included the rate of vegetation, as it is an important variable in explaining the variation in the volume of water discharge of the river tributaries of Wadi Al-Hasa.

The study used modern methods to determine some geomorphological variables: the Arc View of Geographic Information System (Arc View GIS) was used to draw the maps concerned in the study, and for determining the surface topography, the water network and the rate of vegetation for some areas that were difficult to obtain by fieldwork. Moreover, Mathematical equations were used to calculate some variables that contribute in explaining the magnitude of stream floods in Wadi AL- Hasa. The most important of those variables are:

- Coefficient of Variation (CV): In order to determine the extent of regular rains in the basin, the coefficient of variation for the rainy months has been calculated. The coefficient of variation expresses the amount of change in rainfall rates chronologically, both at the level of monthly or annual basis. It is calculated according to the following equation (Eq 1):

$$
\mathrm{CV}=(\mathrm{S} / \mathrm{M}) \times 100
$$

Where $\mathrm{S}$ is standard deviation; $\mathrm{M}$ is arithmetic mean.

- Elongation Ratio (ER): It is calculated according to the following equation (Eq 2):

$$
\mathrm{ER}=\mathrm{A} / \mathrm{L}
$$

Where $\mathrm{A}$ is the diameter of a circle with the same area of the basin $/ \mathrm{km} 2 ; \mathrm{L}$ is the maximum length of the basin / $\mathrm{km}$.

- Hypsometric Index (HI): In order to determine the nature of the basin topography, the hypsometric index of the basin has been calculated according to the following equation (Eq3): 


\section{HI $=\frac{E_{\max }-H_{\max }}{\mathrm{I}_{\max }-\mathrm{H}_{\operatorname{mh}}}$}

Where $\left(\mathrm{H}_{\text {mean }}\right)$ is the mean elevation of the catchment; $\left(\mathrm{H}_{\text {min }}\right)$ is the minimum elevation of the catchment, and $\left(\mathrm{H}_{\max }\right)$ is the maximum elevation of the catchment. $\mathrm{HI}$ can vary from $(0)$ to (1) (Verstraeten and Poesen, 2001).

- Drainage Density (D): It is calculated according to the following equation (Eq 4):

$$
\mathrm{D}=\mathrm{T} / \mathrm{B}
$$

Where $\mathrm{T}$ is the total lengths of the river tributaries of different orders/ $\mathrm{km}$; $\mathrm{B}$ is to the basin area $/ \mathrm{km}^{2}$ (Salama, 1999).

- Stream Frequency (SF): It is calculated according to the following equation (Eq 5):

$$
\mathrm{SF}=\mathrm{W} / \mathrm{B}
$$

Where $\mathrm{W}$ is the total number of waterways of different orders in the basin; $\mathrm{B}$ is the basin area.

-Bifurcation Ratio (BR): It is calculated according to the following equation (Eq 6):

$$
\mathrm{BR}=\mathrm{N} / \mathrm{F}
$$

Where $\mathrm{N}$ is the number of waterways of a certain order: $\mathrm{F}$ is the number of waterways of the following order.

- Water Discharge: The volume of water discharge in waterways of different orders has been measured according to the following equation (Eq.7):

$$
Q=A V
$$

Where $\mathrm{Q}$ is the volume of water discharge $(\mathrm{m} 3 / \mathrm{s}) ; \mathrm{A}$ is the cross-sectional area of the channel $(\mathrm{m} 2) ; \mathrm{V}$ is the speed of water discharge in the channel $(\mathrm{m} / \mathrm{s})$.

- Channel Shape Coefficient: It is calculated according to the following equation (Eq8):

$$
\mathrm{F}=\mathrm{W} / \mathrm{D}
$$

Where $\mathrm{F}$ is channel shape coefficient: $\mathrm{W}$ is Channel width (m); D is channel depth (m)

\section{Basin Environment of Wadi Al-Hasa}

Al-Hasa basin is located in the southern part of the Hashemite Kingdom of Jordan. It extends between longitude $35^{\circ} 32^{\prime}$ and $36^{\circ} 27^{\prime}$ east, and the latitudes $30^{\circ} 30^{\prime}$ and $31^{\circ} 4^{\prime}$ north. The maximum length of the basin is $112.5 \mathrm{~km}$ from east to west, while it extends for $50 \mathrm{~km}$ from north to south (Figure 1).

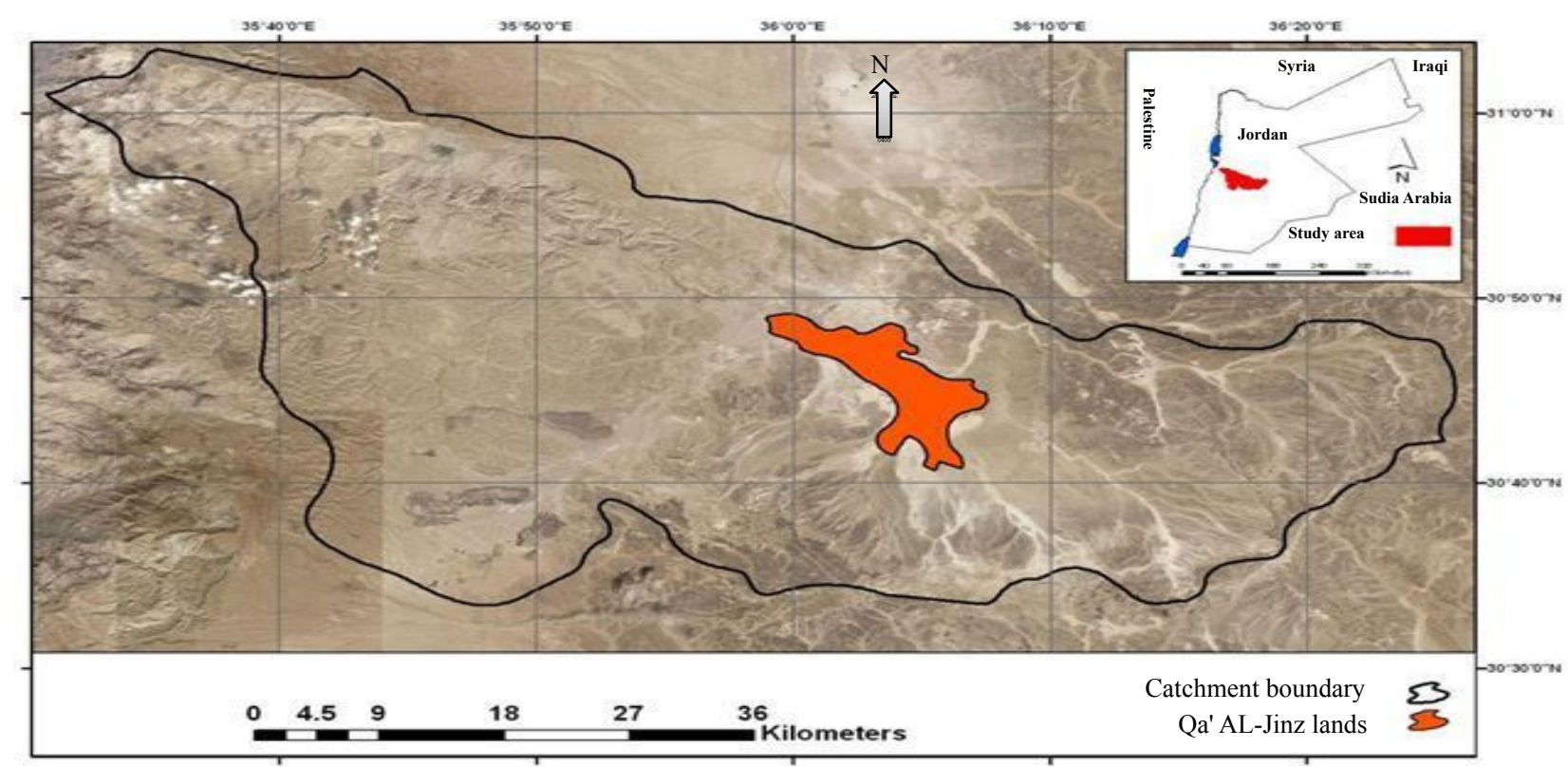

Figure 1. The boundaries of Wadi AL- Hasa basin 
The natural characteristics of the basin affect indirectly the volume of the flood that forms in it. These characteristics include the climate, the soil, the geology and vegetation. The basin environment of Wadi al-Hasa is characterized by drought, as the annual average of rainfall in the basin is less than $(200 \mathrm{~mm})$. It is also characterized by high rates of evaporation, where the annual average of evaporation in Al-Hasa and Al-Hassan / Tafila stations is $(3606 \mathrm{~mm}, 2331 \mathrm{~mm})$ respectively. The estimated monthly rate of evaporation in Al-Hasa station ranges between $(103 \mathrm{~mm})$ in December and $(488 \mathrm{~mm})$ in July, while in Al-Hassan / Tafila station, it ranges between $(80.4 \mathrm{~mm})$ in January and $(359 \mathrm{~mm})$ in July. The high water loss by evaporation in the basin is explained by the high temperature averages in most months of the year, and the exposure of the surface. The annual temperature average has ranged between $\left(19.5^{\circ} \mathrm{C}\right)$ in Al-Hasa station and $\left(17.6^{\circ} \mathrm{C}\right)$ in Al-Hassan / Tafila station. The high loss of rainfall as a result of the high annual average of temperature increases the severity of drought, and reduces the effectiveness of the rainfall in forming water flows that have a high water discharge, and last for long time. This reflects negatively on the volume of runoff water in the Valley and its ability to form stream floods.

As for the soil, there are five types of soils in Al-Hasa basin according to the classification adopted by the Ministry of Agriculture in Jordan in 1993, namely: Typic Calciorthid, Typic Camborthid, Xerochreptic Calciorthid, Calcixerollic Xerochrept, and Typic Xerachrepts (Figure. 2). These soils differ in their ability to increase the severity of water flood formed in the Wadi Al-Hasa according to the water ability to penetrate into their sections, hence, reducing the size of the runoff water.

There are two types of soil that prevail eastern plateau of Al-Hasa basin, namely: Typic Calciorthid and Typic Camborthid. The Typic Calciorthid is considered to be the most prevalent soils in the basin, as it mainly spreads in the eastern regions within the arid moisture-pattern, comprising (39.2\%) of the area of the basin soils. The surface layer of the soil is covered with flint stone gravel and limestone. This layer increases the coefficient of water leakage to soil section due to its high permeability (Ministry of Agriculture, Jordan, 1993). As for the Typic Camborthid, it is found in a limited way in stream valleys and their estuaries in the area of "Qa' Al-Jinz". It represents $(14.5 \%)$ of the area of the basin soils. This soil is characterized by its soft, silt texture; with clay proportion in its section that ranges between $(26.2-38.9 \%)$. It has very low permeability, which increases the amount of water discharge of the river tributaries flowing into the Valley.

The Xerochreptic Calciorthid soil is found in the middle basin within the arid moisture-pattern, representing (20.1\%) of the area of the basin soils. It has a medium permeability, which limits the amount of water discharge of the river tributaries located within its regions.

The Calcixerollic Xerochrept and Typic Xerochrepts soils are found in the western up streams. The Calcixerollic Xerochrept stretches in the form of longitudinal strip within the western highlands. It spreads more in the sloping areas within the gradient category $\left(4^{\circ}-13^{\circ}\right)$, representing $(22.6 \%)$ of the area of the basin soils. The soil's texture is loamy and muddy, and becomes more coherent and harder at $25 \mathrm{~cm}$ deep as a result of the cohesion of soil particles (Ministry of Agriculture, Jordan, 1993). These characteristics contributed to increasing the amount of water flowing in the upper reaches of the Valley. As for the Typic Xerachrepts soil, it exists in a limited way in the northwestern areas within the upper basin area, representing (3.6\%) of the total area of the basin. This type of soil is found within the semi-arid moisture-pattern of the Mediterranean region. Its texture ranges between loamy-muddy in the surface layer and muddy in the lower layers. It is characterized by its high content of mud and low content of sand, which reflected positively on the volume of the water discharge flowing in the upper reaches. 


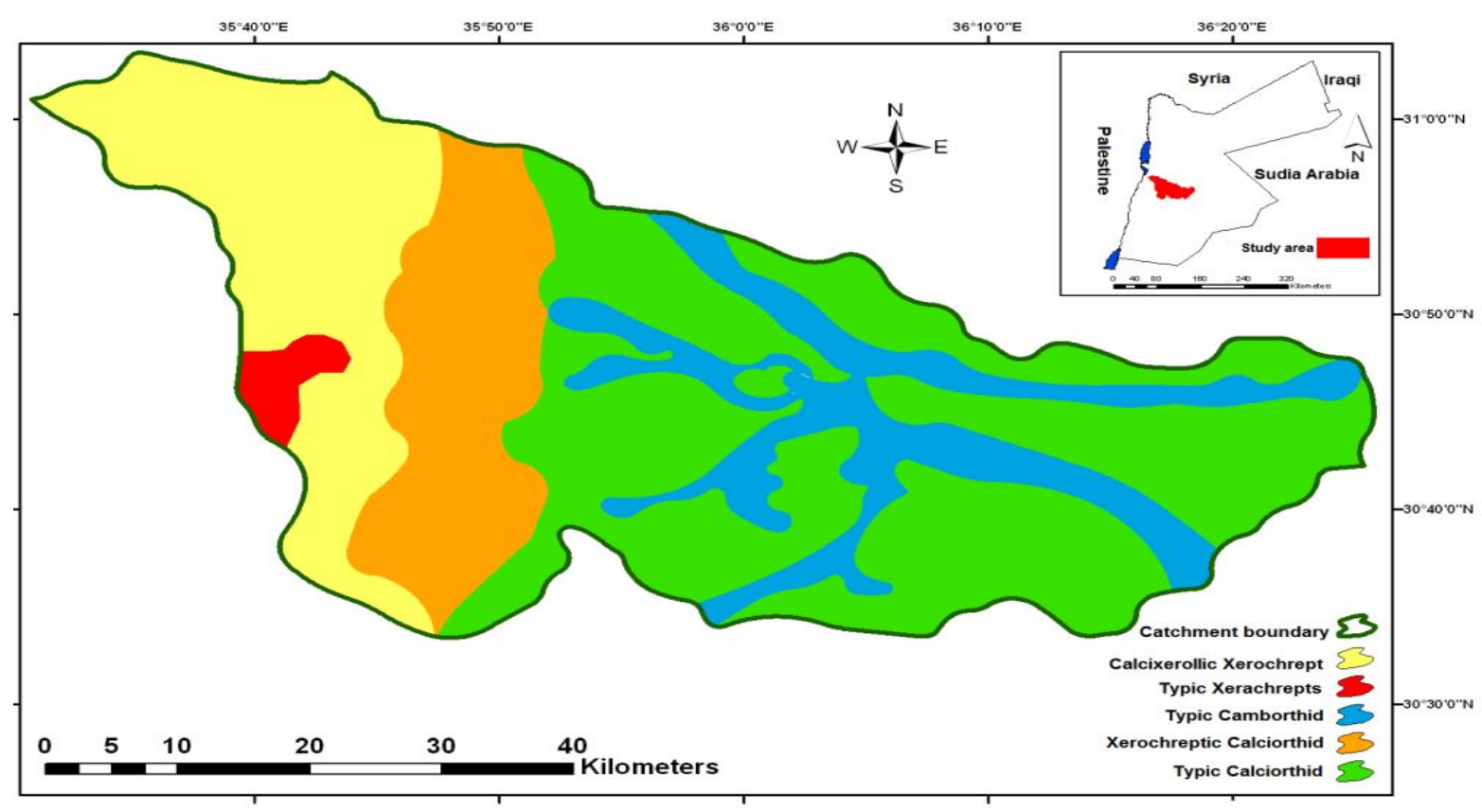

Figure 2. Types of soil in Wadi AL- Hasa basin

As for the geology, there are different types of rock formations spreading in the basin (Figure. 3). In the western upper reaches, there are two types of rock formations, namely: the formation of Wadi Al-Seer (A7) and the formation of Amman (B2). The formation of Wadi Al-Seer consists mainly of lime-dolomite rocks, which is characterized by medium permeability. These formations have been exposed to fractal movements and weathering processes which have contributed to increase their permeability. The composition of Amman consists of limestone, flint stone and phosphate stone. This formation is characterized by a large number of cracks and joints that have contributed directly to increased water leakage rates of flows, and reduced their ability to form a stream floods. This formation goes back to the Campanian Age (Bender, 1974).

In the central areas of the basin, there are two types of formations, namely: the formation of Al-Muwaqqar (B3) and the formation of Um Rjam (B4). The formation of Al-Muwaqqar consists of marl and chalk rocks and it goes back to the Maastrichtian Age (Bender, 1974). It features an abundance of joints and cracks, which increases the permeability of this formation and therefore reduces the coefficient of water flow of the river tributaries that their riverbeds are formed from this formation. The formation of Um Rjam (B4) is composed of flint-limestone which goes back to the Tertiary era of modern life. It is characterized by medium permeability which increases the size of water discharge of the river tributaries that their riverbeds are formed from this formation.

The surface formations of the eastern plateau of the basin consists of valleys sediments - except the northern areas of the plateau which consists of Ajlouns lower formations These sediments consist of rock debris of flint, limestone, boulders and dirt and go back to the Pleistocene Age. They are characterized by their high permeability which reduces the volume of water discharge in the valleys, and causes a delay in the velocity of water flow to the main stream, hence, reducing the possibility of flooding. 


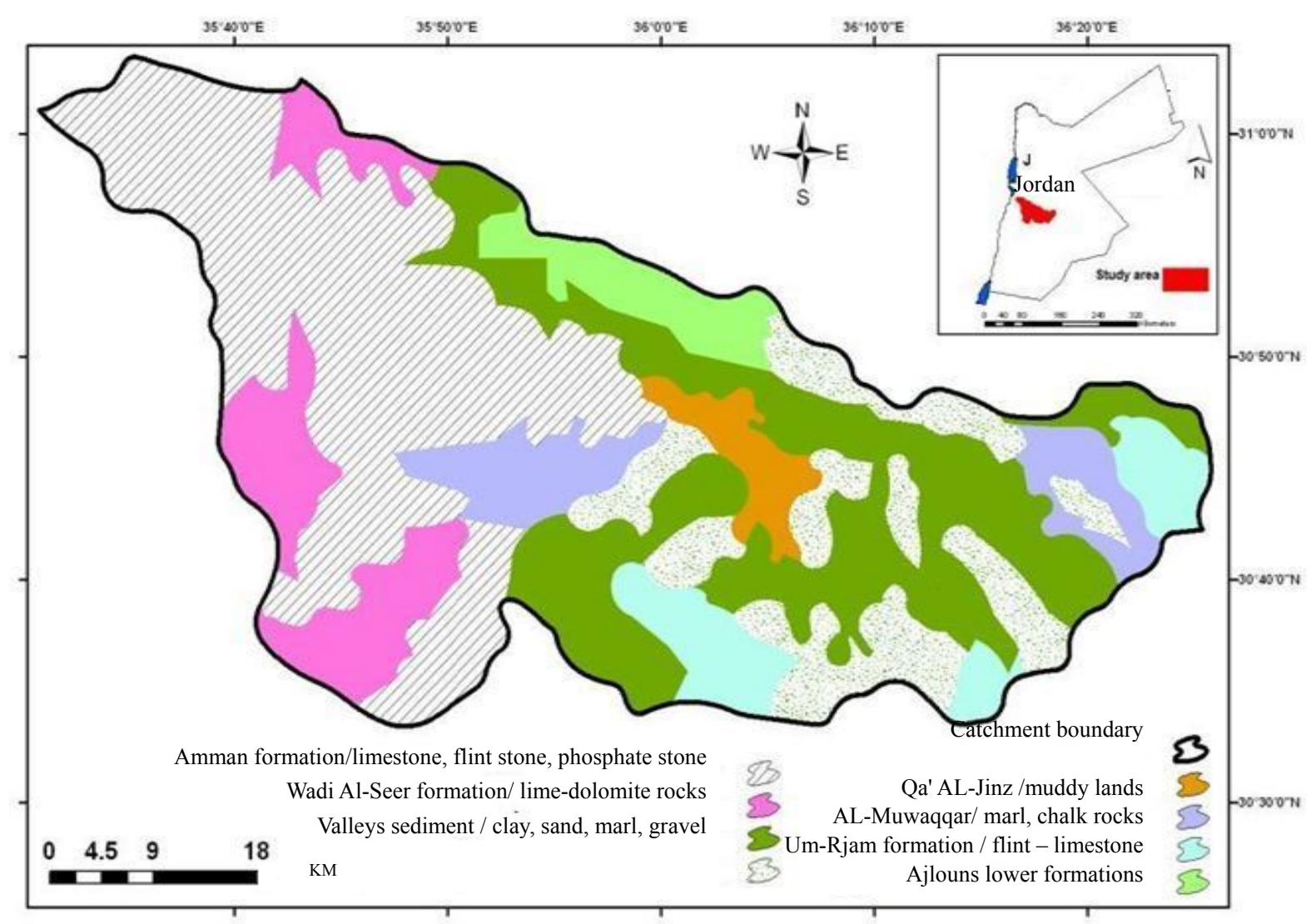

Figure 3. Surface formation in Wadi AL-Hasa basin

The vegetation in Wadi Al-Hasa is characterized by its low density and being limited to specific types of plants that adopt with the conditions of its arid basin environment. Some of the most important of these plants are: Achillea Fragrantissima, Artemisia Herba-alba, Poa Sinaica, Cynodon Dactylon, Anabasis Haussknechtii, Peganum Harmala Noaea Mucronata, and Launaea Spinosa.

The proportion of coverage of these plants varies. They are denser in the western highlands due to the higher rainfall rates and good soil properties compared with the eastern regions. The vegetation ratio in the basin can be classified as follows:

1) Regions where the vegetation ratio is less than (10\%). The flora in these regions is rare. They represent the land adjacent to the eastern valleys streams, and the muddy lands of Q'al Al-Jinz. The role of vegetation is limited due to low density.

2) Regions in which the vegetation ratio ranges between (11-18.78\%). These regions represent the western valleys streams and adjacent areas; and convergence areas of tributaries with the main tributary of Wadi Al-Hasa. The increase in vegetation in these areas reduces the magnitude and volume of water discharge of stream floods which are formed in the basin after rainstorms because of the vegetation's ability to increase the soil's permeability, and impede the movement of runoff water.

\section{Results and Discussion}

\subsection{Geomorphological Variables that Determine the Magnitude of Stream Floods in Wadi Al-Hasa}

The magnitude and severity of stream floods depend on a set of variables that directly determine the volume of water discharge in the channels. These variables are as follow:

\subsubsection{Rainfall}

Most stream floods in the Valley are formed as a result of rain storms associated with low depressions that affect the western highlands of the basin in winter. These rain storms are characterized by irregularity, heavy rainfall, and being concentrated in short time periods. The rainfall rate in these storms is around $(45 \mathrm{~mm})$, and the severity of their impact relies on the severity of the low depression which affects the region. 
Table 1 shows the values of rainfall recorded in the climatic stations, Al-Hasa and Al-Tafeelah that represent the basin area during the period (1975-2013). Al-Tafeelah station represents the characteristics of rainfall in the upper basin, while Al-Hasa station represents the characteristics of rainfall in the lower basin. Some data are extrapolated from the analysis of the table regarding the characteristics of rainfall in the basin, namely:

1. Rainy season begins in October and lasts until the end of May. This period agrees with the beginning of low depressions affecting the area and recurrence of weather instability. The fluctuation in the monthly rainfall in the basin and the lack of rain in some months of the year causes the occurrence of periods of drought that negatively affect the volume of water flowing in the Valley.

The winter months (December, January, and February) are considered to be the most months with regular rainfall when compared to the rest of the months. The coefficient of variation for these months in Al-Hasan / Tafila station and Al-Hasa station is $(73 \% .75 \% .93 \%),(76 \% 0.82 \% 0.84 \%)$ respectively. The chronological fluctuation of rainfall in the months increases as we head eastward, as the coefficient of variation in Al-Hasa station ranged between $(76 \%$ - 184.6\%).

2. The standard deviation Indicates the amount of deviation from the average for each month during the period (1975 - 2013), as this average in Al- Hassan / Tafila station and Al-Hasa station ranged between (7.6 $-50.3),(4.8-15.1)$ respectively. This deviation is explained by monthly rainfall rate variability and irregularity.

3. The western areas of the basin are characterized by receiving the most rainfall compared with the eastern areas. The highest amount of rainfall in January at Al-Tafeela station reached $(395.5 \mathrm{~mm})$, while at A-Hasa it reached $(45.5 \mathrm{~mm})$ for the same month. These high amounts of rainfall and their long duration in the western areas are resulting from successive rainstorms in the winter, which form fast water flows in the upper reaches of the Valley. The impact of those storms and their ability to form water flows is increased by the steepness of the basin's surface $\left(2.9^{\circ}-23^{\circ}\right)$, and its rising to (1100 meters) above sea level. On the other hand, rainfall in the eastern areas is limited to deep low depressions.

The incessant rainfall on the area of the upper reaches contributes to the continuity of water flow in the upper reaches of first and second orders; those in turn meet with tributaries of third and fourth orders in the middle part of the basin's course. This convergence of tributaries of different orders increases the amount of water discharge into the higher order streams that feed the mainstream of Wadi Al-Hasa, leading to an increase in the magnitude and competence of water discharge in the mainstream.

Table 1. Chronological fluctuation of rain in Al-Hassan Station / Tafila and Al-Hasa Station at the level of rainy months during the period 1975-2013

\begin{tabular}{|c|c|c|c|c|c|c|c|c|}
\hline \multirow[t]{2}{*}{ Month } & \multicolumn{4}{|c|}{ Al-Hasan Station / Tafeela* } & \multicolumn{4}{|c|}{ Al-Hasa Station** } \\
\hline & $\begin{array}{l}\text { Monthly } \\
\text { average } \\
\text { mm. }\end{array}$ & $\begin{array}{l}\text { Highest } \\
\text { rainfall } \\
\text { amount } \\
\text { mm. }\end{array}$ & $\begin{array}{l}\text { Standard } \\
\text { deviation }\end{array}$ & $\begin{array}{l}\text { Coefficient } \\
\text { of variation }\end{array}$ & $\begin{array}{l}\text { Monthly } \\
\text { average } \\
\text { mm. }\end{array}$ & $\begin{array}{l}\text { Highest } \\
\text { rainfall } \\
\text { amount } \\
\text { mm. }\end{array}$ & $\begin{array}{l}\text { Standard } \\
\text { deviation }\end{array}$ & $\begin{array}{l}\text { Coefficient } \\
\text { of } \\
\text { variation } \%\end{array}$ \\
\hline October & 18.5 & 22.7 & 18.7 & 103 & 12.3 & 20.2 & 13.2 & 107 \\
\hline November & 27.5 & 82.6 & 26.3 & 95 & 5.5 & 21.6 & 9.3 & 169 \\
\hline December & 36.5 & 169 & 26.7 & 73 & 14.8 & 43.4 & 11.3 & 76 \\
\hline January & 67.3 & 395.5 & 50.3 & 75 & 15.8 & 97.9 & 14 & 82 \\
\hline February & 29.4 & 174.3 & 27.2 & 93 & 16.6 & 40.7 & 13 & 84 \\
\hline March & 18.9 & 84.9 & 19.2 & 102 & 14.3 & 31.2 & 15.1 & 106 \\
\hline April & 9.6 & 94.5 & 11.3 & 118 & 5.4 & 13 & 9.4 & 175 \\
\hline May & 6.6 & 10.2 & 7.6 & 115 & 2.6 & 18.1 & 4.8 & 184.6 \\
\hline
\end{tabular}

Source: Prepared by the researcher 。

$*$ represents the western regions $\quad * *$ represents the eastern regions

Figure 4 shows the volume of water discharge in Wadi Al-Hasa after being affected by a series of rainstorms associated with the polar low that hit the region from 11/12/2013-14/12/2013. The water discharge rate in the Valley steadily increased with the increase of rainfall. The highest amount of water discharge $\left(37 \mathrm{~m} \mathrm{~m}^{3} / \mathrm{s}\right)$ coincided with the intensity of rainfall, which reached $(29 \mathrm{~mm} / \mathrm{h}$.) in the third day of the storm. This direct proportion can 
be explained as follows: the increasing amount of precipitation during a short period of time increases the coefficient of water flow due to lower soil capacity to be saturated in a short period of time; at the beginning of the storm, the soil's ability to filter water through its pores is high, but this ability soon begins to decline with the continued and increasing rates of precipitation in the subsequent hours of the rainstorm.

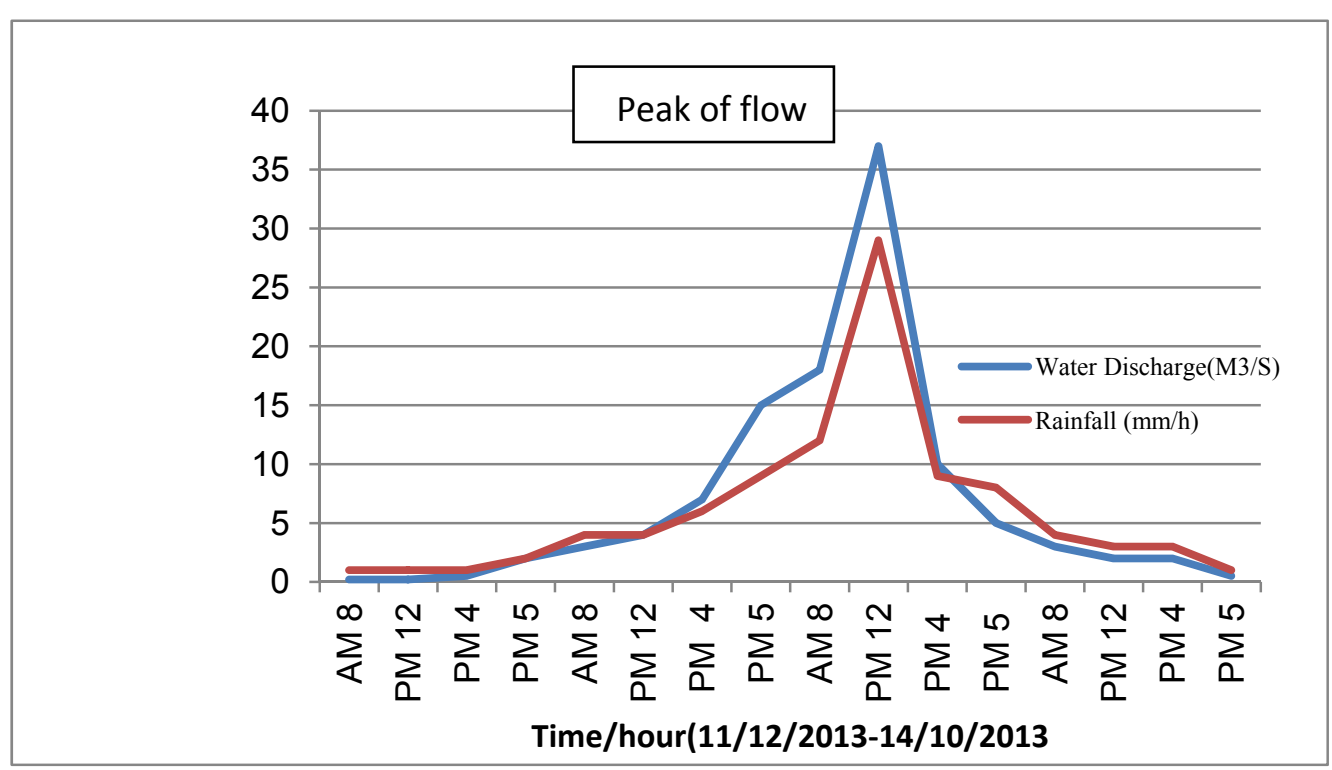

Figure 4. The volume of water discharge in Wadi Al-Hasa after being affected by a series of Rainstorms associated with the polar low that hit the region from 11/12/2013-14/12/2013

The following facts are made clear by the analysis of water discharge values of two stream floods which occurred in Wadi Al-Hasa and their relation to the characteristics of rainstorms that affected the basin during these floods (Figures. 5, 6):

1. The water discharge volume of the flood increases with the increase in the rainfall concentration rate and its brevity, as the highest volume of water discharge of the first and second floods reached $\left(56 \mathrm{~m}^{3} / \mathrm{s}\right)$ and $(72$ $\mathrm{m}^{3} / \mathrm{s}$ ) respectively, with rainfall concentration rate ranged between $(15-30 \mathrm{~mm} / \mathrm{h})$.

2. The peak of water discharge of the flood is linked to the shortness of time periods after the rainfall on the basin, as the length of time period needed to reach the peak of water flow ranged between ( $3-6$ hours). This indicates the importance of rainfall concentration in determining the time at which water flow reaches its peak.

3. The disparity in the amount of rainfall from rainstorms make a clear difference in the magnitude and severity of stream floods formed in Wadi Al-Hasa after being influenced by rainstorms, as the intensity of rainfall from those storms which caused the floods ranged between $(15-30 \mathrm{~mm} / \mathrm{h})$. 


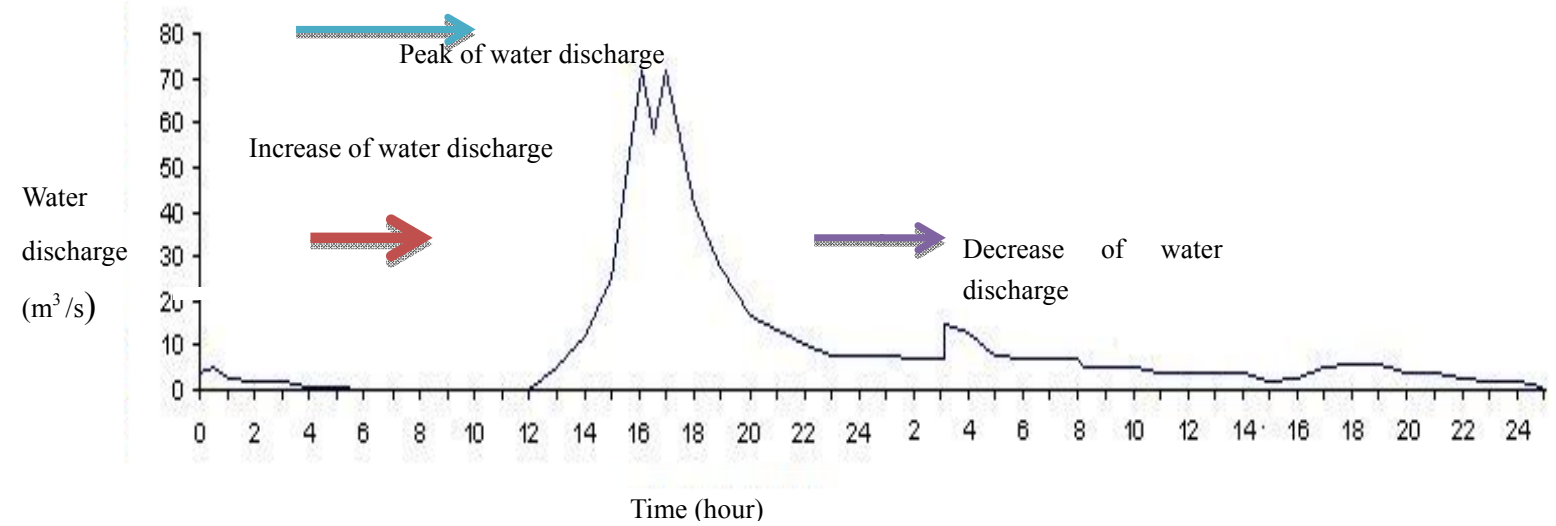

Figure 5. The volume of water discharge of a flood that occurred in Wadi AL- Hasa during the period 1970-1971 (JICA, 1990)

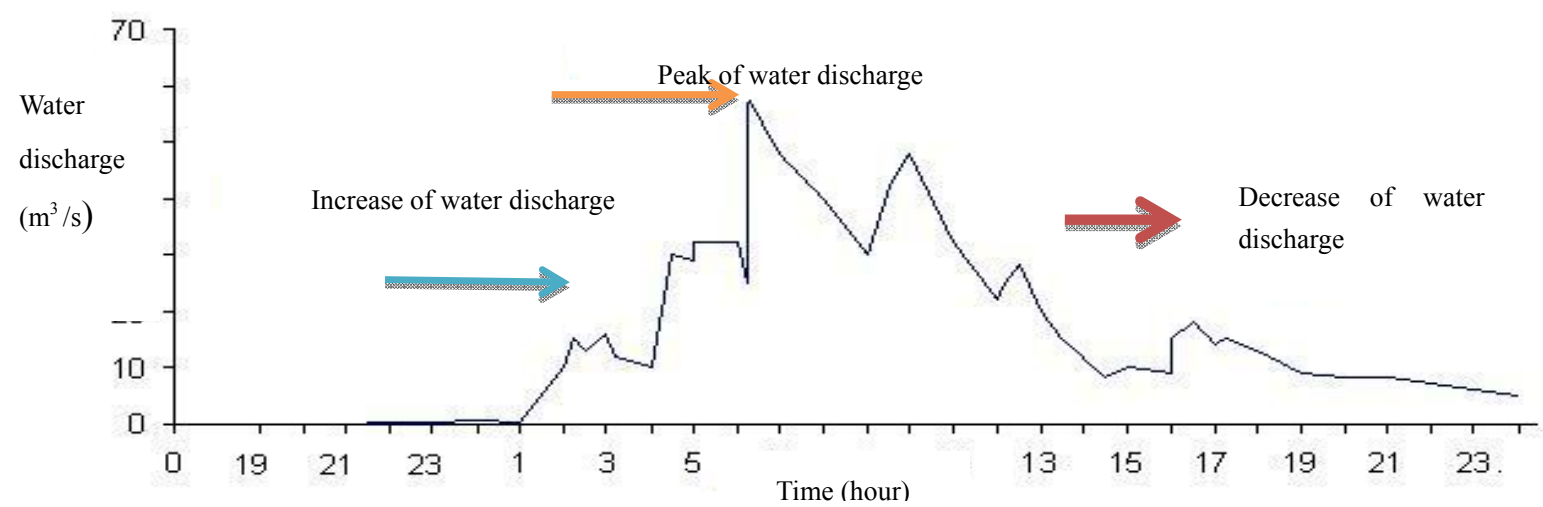

Figure 6. The volume of water discharge of a flood that occurred in Wadi AL- Hasa during the period 1971-1972 (JICA, 1990)

The magnitude and severity of stream floods in Wadi Al-Hasa are synced with the arrival of water flow to its peak. Table 2 shows the maximum volume of water discharge for three major stream floods occurred in Wadi Al-Hasa during the period (1971-1982), where it ranged between $\left(41.1 \mathrm{~m}^{3} / \mathrm{s}-78 \mathrm{~m}^{3} / \mathrm{s}\right)$.

Table 2. The volume of watery discharge and the amount of rainfall and the rate of concentration in four major stream floods occurred in Wadi Al-Hasa

\begin{tabular}{lcc}
\hline \multicolumn{1}{c}{$\begin{array}{c}\text { Flood No/ Date of } \\
\text { stream flood }\end{array}$} & $\begin{array}{c}\text { Total of rainfall in } \\
\text { Gaging Station } \\
\text { CD0013 / mm. }\end{array}$ & Peak of discharge $\mathrm{m}^{3 / \mathrm{s}}$ \\
\hline H15/ 1 Des.07 - 1971 & 92.5 & 78 \\
H23/ Nov.11-13 - 1973 & 12.3 & 16.5 \\
H50/Nov. 22- 26 - 1982 & 22.4 & 41.1 \\
Average & 42.4 & 45.2 \\
\hline
\end{tabular}

Source: (JICA, 1990).

\subsubsection{Shape and Areal Dimensions of the Basin}

The large basin area of the Valley $\left(2198 \mathrm{~km}^{2}\right)$ increases the geomorphologic effectiveness of the rainfall on the basin, where the extended area of the basin helps to accommodate large amounts of rainfall which develops basin floods with high water discharge. On the other hand, the extended area also increases the volume of water flow in the upper stream area due to the vastness of watershed area that receives large amounts of rain, which in turn, 
contributes to the rapid formation of water flows in most western tributaries that feed the Valley. These tributaries increase the amount of water discharge and its hydrological ability to cause stream floods. The catchment shape is nearly rectangular, where the elongation ratio reaches about $(69.31 \%)$. This ratio affected the morphometric characteristics of the tributaries of lower orders, as these tributaries tend to reduce their length and increase their number to match the areal shape of the basin. This morphometric change in the tributaries affected the hydrology of their water flows in terms of their speed to reach their estuaries from the tributaries of higher orders. The width of the basin changes from one region to another, where it widens in the upstream region and narrows in the downstream region, as evidenced by the low values of the coefficient of the basin shape (42). This widening in the upstream area has led to the increase in the amount of rainfall received, forming fast water flows in the upper reaches arriving to the mainstream within short period of time (Table, 3).

Table 3. Shape, areal and relief Characteristics of Al-Hasa Basin

\begin{tabular}{llll}
\hline Shape and areal Characteristics & & Relief Characteristics & \\
\hline Basin area $\mathrm{km}^{2}$ & 2198 & Relief M & 1583 \\
Elongation Ratio \% & 69.31 & Relief Ratio m / km & 31.6 \\
Catchment width/depth ratio & 42 & Hypsometric Integral \% & 79 \\
The gradient rate of the & $2.4-6.8^{\circ}$ & Gradient rate of the lateral hillsides & $8-14^{\circ}$ \\
mainstream & Sinuous & The highest peak of the basin M & 1173 \\
The general shape of the basin & & &
\end{tabular}

\subsubsection{The Topography of the Surface}

The topography of the basin surface is varied. The height of the surface ranges between (1173 meters) above sea level in the upper reaches areas and (410 meters) below sea level at its estuary. Figure 7 shows the topography of Wadi Al-Hasa basin, where it appears from the analysis of this figure that the basin of the Valley is characterized by its surface relief (the surface relief represents the difference between the highest and the lowest points of the basin) where the relief rate in the basin reached $(1583 \mathrm{~m})$ and the relief percentage reached $(31.6 \mathrm{~m} / \mathrm{km})$.

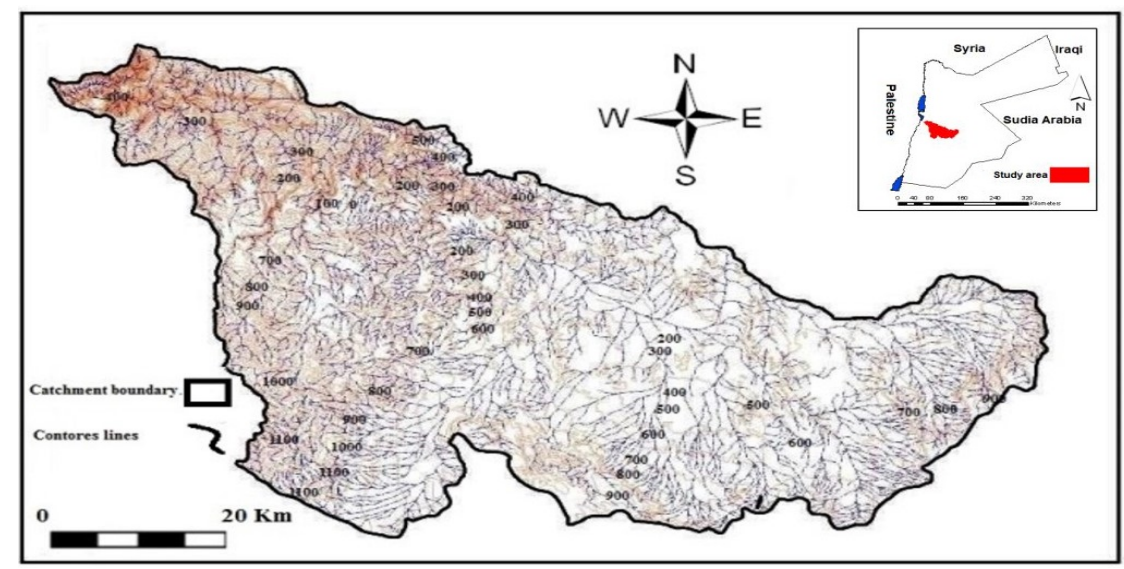

Figure 7. The topography of Wadi AL-Hasa and water network (Source: Topographic Maps, 2008)

This surface relief is due to tectonic processes that hit the downstream area and the consequent activation of water erosion processes that led to high density of discharge network and deeper valleys, where the gradient rate of the lateral hillsides overlooking the mainstream ranged between $\left(8^{\circ}-14^{\circ}\right)$. The impact of surface relief is manifested in increasing the magnitude of the stream floods through increasing the speed of the water flows in the tributaries to reach their estuaries, hence, syncing the occurrence of stream flood with the maximum water flow in the Valley.

The hypsometric index of the basin (79\%) indicates a rugged topography which increases the speed of forming water flows flowing to the river tributaries and then into the mainstream. The continuity of water flow in the river tributaries toward the Valley leads to an increase in the speed at which the water flow in the mainstream 
reaches its peak.

The surface topography of the basin also determines the direction of the flow in the valley; as it is heading from east, where the eastern plateau with little sloping, towards the west, where its estuary area with severe. The gradient rate of the mainstream ranges between $\left(2.4^{\circ}-6.8^{\circ}\right)$ (Figure. 8).

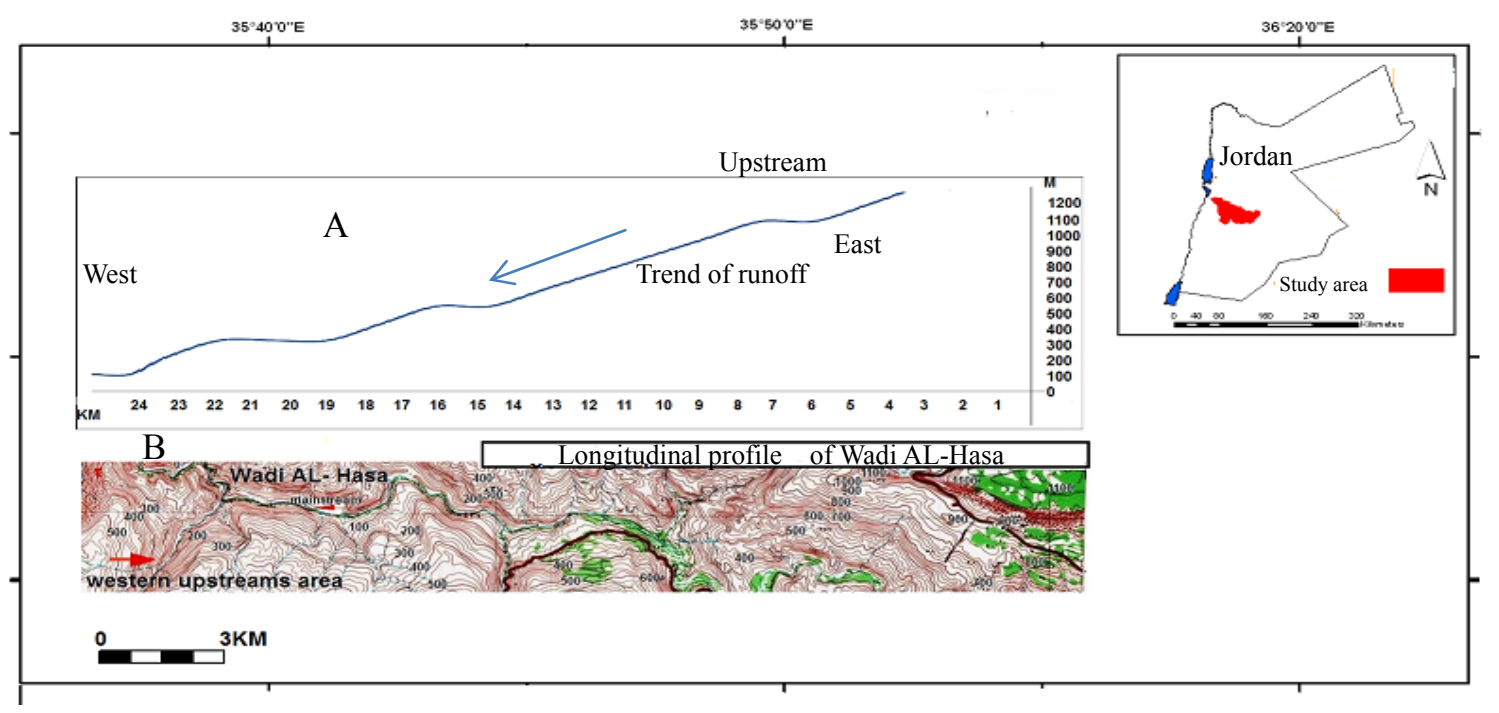

Figure 8. Longitudinal profile of Wadi AL-Hasa mainstream

The amount of change in the gradient degree of the Valley depends on the rate of vertical erosion which the stream bed undergoes as a result of the water flow in the mainstream. The erosion ability depends on the volume of the discharge water and its flow speed throughout the course of the Valley. The vertical erosion ability of the water flow has increased in the periods in which Wadi Al-Hasa underwent tectonic processes at its estuary area (the Dead Sea), causing a marked increase in the gradient rate of the stream in the upper and middle basin and a consequent decline in the rate of water leakage. The increase in the gradient rate increases the speed of water flow in the upper tributaries of the Valley towards the mainstream, which makes the likelihood of flooding in the Valley linked to the continuity of water discharge in those tributaries.

\subsubsection{Water Network}

The western tributaries of Wadi Al-Hasa water network take the tree drainage pattern, while its eastern tributaries that feed Qa' Al-Jinz take the central drainage pattern. The characteristics of the water network affect directly the magnitude and volume of stream floods which form in Wadi Al-Hasa after rainstorms. The drainage density, the stream frequency, the bifurcation ratio and the stream order are the most important of these characteristics.

The overall drainage density of the basin is $\left(1.27 \mathrm{~km} / \mathrm{km}^{2}\right)$. This is a high drainage density compared with other water basins in southern Jordan (Table 4).

The drainage density in the upstream area climbs up to $\left(7.9 \mathrm{~km} / \mathrm{km}^{2}\right)$ which indicate the high number of water channels on the surface, and the extent of convergence in the distance between waterways in these areas. This convergence affects the speed at which water discharges of the streams of different orders meet with each other as a result of the low rate of water leakage in the western waterways that flow into Wadi Al-Hasa. This increases the likelihood of flooding in the Valley.

The average of stream frequency of Al-Hasa basin is $\left(0.53\right.$ stream $\left./ \mathrm{km}^{2}\right)$. It increases in the upstream area of the basin due to the increase in the intensity of the river tributaries in the area unit, as well as a result of the increase in the annual average of rainfall and rough surface; and the subsequent activation of the river erosion processes and its ability to form river channels.

The bifurcation ratio of the basin reached (4.46). This ratio increases in the upstream area as a result of high rates of rainfall in these regions. This increase helps those regions to accommodate the increasing amount of rainfall which takes the form of waterways. Hence, the amount of water discharge that feed the streams of higher orders in those areas is increased, making stream floods more likely to take place. 
The waterways that flow into Wadi Al-Hasa differ in their stream order from $1^{\text {st }}$ to $5^{\text {th }}$ (mainstream). These stream orders vary in the number of their waterways. The first order has the most waterways, it has (891) waterways; followed by the second order with (363) waterways; then the third order with ( 52 ) waterway; next the fourth order with ( 7 ) waterways; and finally the fifth order which represents the mainstream. Thus, the waterways of the first order can be considered the spine which feeds the water flow in the mainstream during the rainy season. Moreover, the presence of a large number of waterways from the first and second orders in the headwaters area near the watershed of the basin has led to the accommodation of the rainfall quantities falling on the headwaters area, and taking the form of water channels.

Stream orders differ in their length and their gradient degrees. Waterways of the first order are characterized by their shortness and steepness, as their average length reached $(0.62 \mathrm{~km}$.) while their gradient degree reached $\left(6.5^{\circ}\right)$. These characteristics increase the volume of water flow in those waterways due to its high flow speed and the shortness of distance travelled towards its estuary. On the other hand, waterways of higher orders (second, third, and fourth) are characterized by their long course and their low steepness. This negatively affects the volume of water flow due to its low flow speed. The gradient degree of those waterways ranged between $(4.2-$ $\left.5.3^{\circ}\right)$ while their average length ranged between $(1.1-7.9 \mathrm{~km})$.

Table 4. Water Network Characteristics in Al-Hasa Basin

\begin{tabular}{lc}
\hline \multicolumn{2}{c}{ Water Network Characteristics } \\
\hline Drainage Density & $1.27 \mathrm{~km} / \mathrm{km}^{2}$ \\
The drainage density in the upstream & $7.9 \mathrm{~km} / \mathrm{km}^{2}$ \\
Stream Frequency Rate & $0.53 \mathrm{stream} / \mathrm{km}^{2}$ \\
Bifurcation Ratio & $4.46 \mathrm{stream} /$ higher order stream \\
Stream Order of the Valley & 5 \\
\hline
\end{tabular}

\subsubsection{The Volume of Water Discharge in Waterways of Different Orders}

Waterways depend in their development on the volume of water discharge flowing in their channels. This development reflects a kind of dynamic balance between the volume of water discharge and the capacity of the channels. Any disruption of this balance results in stream floods. The stream order reflects the stages of waterways development and the ability of their channels to accommodate water flows after rainfall.

Table 5 shows the rate of water discharge in waterways in Wadi Al-Hasa according to their stream orders during the rainy season (2013/2014). By analyzing the table, it is evident that the volume of water discharge in waterways increases with the increase in their stream order due to the expected increase in the volume of feeding water from the river tributaries flowing in tributaries of higher stream orders; thus, increasing the chances of forming stream floods in the basin, mainly in the higher stream orders and in the mainstream due to the increase in their water discharge. The rate of water discharge in the river tributaries of the first and second orders is $(0.18$ $\left.\mathrm{m}^{3} / \mathrm{s}, 0.25 \mathrm{~m}^{3} / \mathrm{s}\right)$; the third and fourth orders is $\left(0.39 \mathrm{~m}^{3} / \mathrm{s}, 0.54 \mathrm{~m}^{3} / \mathrm{s}\right)$; and it stood at $\left(0.93 \mathrm{~m}^{3} / \mathrm{s}\right)$ for Wadi Al-Hasa.

Table 5. The morphometric characteristics of waterways and the volume of their water discharge in Al-Hasa basin during the rainy season (2013/2014)

\begin{tabular}{ccccccc}
\hline $\begin{array}{c}\text { Stream } \\
\text { Order }\end{array}$ & $\begin{array}{c}\text { Number of } \\
\text { waterways }\end{array}$ & $\begin{array}{c}\text { Average } \\
\text { Length of } \\
\text { waterways } \\
(\mathrm{km})\end{array}$ & $\begin{array}{c}\text { Bifurcation } \\
\text { Stream of each } \\
\text { stream order }\end{array}$ & $\begin{array}{c}\text { Gradient } \\
\text { rate of of } \\
\text { each stream } \\
\text { order }\left({ }^{\circ}\right)\end{array}$ & $\begin{array}{c}\text { The } \\
\text { cross-sectional } \\
\text { area of the } \\
\text { channel }\left(\mathrm{m}^{2}\right)\end{array}$ & $\begin{array}{c}\text { Water } \\
\text { Discharge rate } \\
\text { of each stream } \\
\text { order }\left(\mathrm{m}^{3 /} \mathrm{s}\right)\end{array}$ \\
\hline First & 891 & 0.62 & 2.45 & 6.5 & 0.31 & 0.18 \\
Second & 363 & 1.1 & 6.98 & 5.3 & 0.51 & 0.25 \\
Third & 52 & 4.4 & 7.43 & 4.6 & 0.63 & 0.39 \\
Fourth & 7 & 7.9 & 7 & 4.2 & 0.81 & 0.54 \\
Fifth & 1 & 49.8 & - & 3.9 & 2.1 & 0.93 \\
(main & & & & & & \\
stream) & & & & & & \\
\hline
\end{tabular}


Table 6 shows the results of the stepwise regression analysis of the geomorphological variables that determine the volume of water discharge in the river tributaries, where the geomorphological variables interpreted (53\%) of the total variation in the volume of water discharge in the river tributaries. The stream order variable came first in terms of importance in the interpretation of the variation in the volume of the water discharge in the tributaries. The percentage of interpretation for this variable was $(22 \%)$ with statistical significance $(0.0001)$, while the correlation coefficient indicated a strong positive relationship between the two variables $(77 \%)$ with statistical significance (0.0001); the gradient degree variable came second, it interpreted (14\%) of the total variation with statistical significance (0.001), while the correlation coefficient indicated the existence of a strong relationship between the two variables $(70 \%)$ with statistical significance $(0.001)$; the width of the channel variable came in third place, the percentage of interpretation for this variable was (11\%) with statistical significance $(0.025)$, while the correlation coefficient indicated a strong positive relationship between the two variables (66\%) with statistical significance $(0.03)$; the vegetation variable came in fourth place, it interpreted $(6 \%)$ of the variation, with statistical significance $(0.05)$, as the correlation coefficient indicated a moderate negative relationship between the two variables $(61 \%)$ with statistical significance $(0.048)$.

Table 6. The Results of the Statistical Analysis of the Stepwise Regression of the Morphometric and Hydrological Variables That Determine the volume of water discharge in the river tributaries in Wadi Al-Hasa

\begin{tabular}{lcccc}
\hline The Variable & $\begin{array}{c}\text { Interpretation } \\
\text { Percentage } \%\end{array}$ & $\begin{array}{c}\text { Statistical } \\
\text { Significance }\end{array}$ & $\begin{array}{c}\text { Correlation } \\
\text { Coefficient }\end{array}$ & $\begin{array}{c}\text { Statistical } \\
\text { Significance }\end{array}$ \\
\hline Stream order & 22 & 0.0001 & 77 & 0.0001 \\
$\begin{array}{l}\text { Gradient } \\
\begin{array}{l}\text { Width of } \\
\text { channel }\end{array}\end{array}$ & 14 & 0.0001 & 70 & 0.0001 \\
Vegetation & 11 & 0.025 & 66 & 0.03 \\
\hline
\end{tabular}

\subsubsection{The Morphology of the River Channel and the Morphological Variables That Determine Its Capacity}

The development of the morphological shape of the water channels in Wadi Al-Hasa depends on the changes that occur in the erosive force of the runoff water flowing in them and its ability to form their banks and stream beds. This ability is linked to two natural operations, namely: the vertical erosion of the stream bed and the lateral erosion of the banks. The role of the lateral erosion is manifested in its ability to transport fluvial bank materials by increasing the flow forces of the runoff water that operate on the surface of the banks; these forces are: the drag force, the resistance force, and the lifting force. As for the vertical erosion, its activity is increased with the occurrence of a drop down in the river estuary area. The capacity of the water channels increases with the increase in the vertical erosion of the stream bed and the lateral erosion of the banks due to the increased areal dimensions of the water channels (width, depth) there by increasing the cross-sectional area of the channel through which the water discharge flows. The cross-sectional area of the channel can be calculated by multiplying its width by its depth. The capacity of the water channel also increases with the increase in the cross-sectional area, which in turn depends on the geomorphological development of the channel and the increase in its stream order. The average cross-sectional area of the water channels of the first and second order is $\left(0.31 \mathrm{~m}^{2}, 0.51 \mathrm{~m}^{2}\right)$; the third and fourth orders is $\left(0.63 \mathrm{~m}^{2}, 0.81 \mathrm{~m}^{2}\right)$; while the average cross-sectional area of the fifth order (the mainstream) amounts to $\left(2.1 \mathrm{~m}^{2}\right)$.

The stream floods in Wadi Al-Hasa represent some kind of imbalance between the capacity of the river channel and the amount of water discharge. Hence, the flood occurs when the water level in the river channel exceeds its threshed, leading to a surge of water over the banks of the river that inundate large areas of land adjacent to them. Therefore, the recurrence of the flood; and its continuity and severity; depend on the balance between the water level in the river channels and their capacity. The morphological role of the channel is evidenced by determining its shape pattern, which can be determined by calculating the channel shape coefficient.

The shape coefficient of the water channels in the Valley ranges between (6.4- 23.6) and the rate of (15.6). This difference in the shape coefficient is due to the variation in water erosion force affecting the stream bed and its banks.

The cross-sections of the water channels in Wadi Al-Hasa take the U-shape where the banks are too steep and exceed (15) degrees, and the channel bottom is flat with a variation in its width and depth; the V-shape where the banks are a little steep ranging between (7-15) degrees, and its depth exceeds its width; and the scattering shape, 
in which the width of the channel extends to several meters and its depth declines to a few centimeters.

The shape of the channel affects the volume and speed of the water flow, and the channel ability to accommodate the increase in the water level. Most of the river channels of the western tributaries take the U-shape; while most of the river channels of the eastern tributaries that follow the central drainage pattern and flow into Qa' Al-Jinz, take scattering shape. The channel shape of Wadi Al-Hasa takes the V-shape as we approach the western upstreams area and it takes the U-shape as we approach its estuary area (the Dead Sea); while it takes the scattering shape in the eastern tributaries flowing into Qa' Al-Jinz. The scattering shape has helped to cause stream floods in this region as a result of its low capacity and the inability of its banks to stand up for the erosion forces exerted on them by the increased water flow in the river channel.

\subsection{The Geographical Distribution of Flooding Areas in Wadi Al-Hasa}

After analyzing the environment-related geomorphological variables of Wadi Al-Hasa, three major regions with increased possibility of flooding were identified, namely:

1. The estuaries of the eastern tributaries in Qa' Al-Jinz area. The possibility of flooding in these areas within the normal level.

2. The areas where the western tributaries of higher orders meet and the adjacent area especially wadi ALNaqi' area in Ghor AL- Safi. The likelihood of flooding in these areas within the middle level.

3. The estuary area of the main Valley. The possibility of flooding in these areas within the high level (Figure. 9).

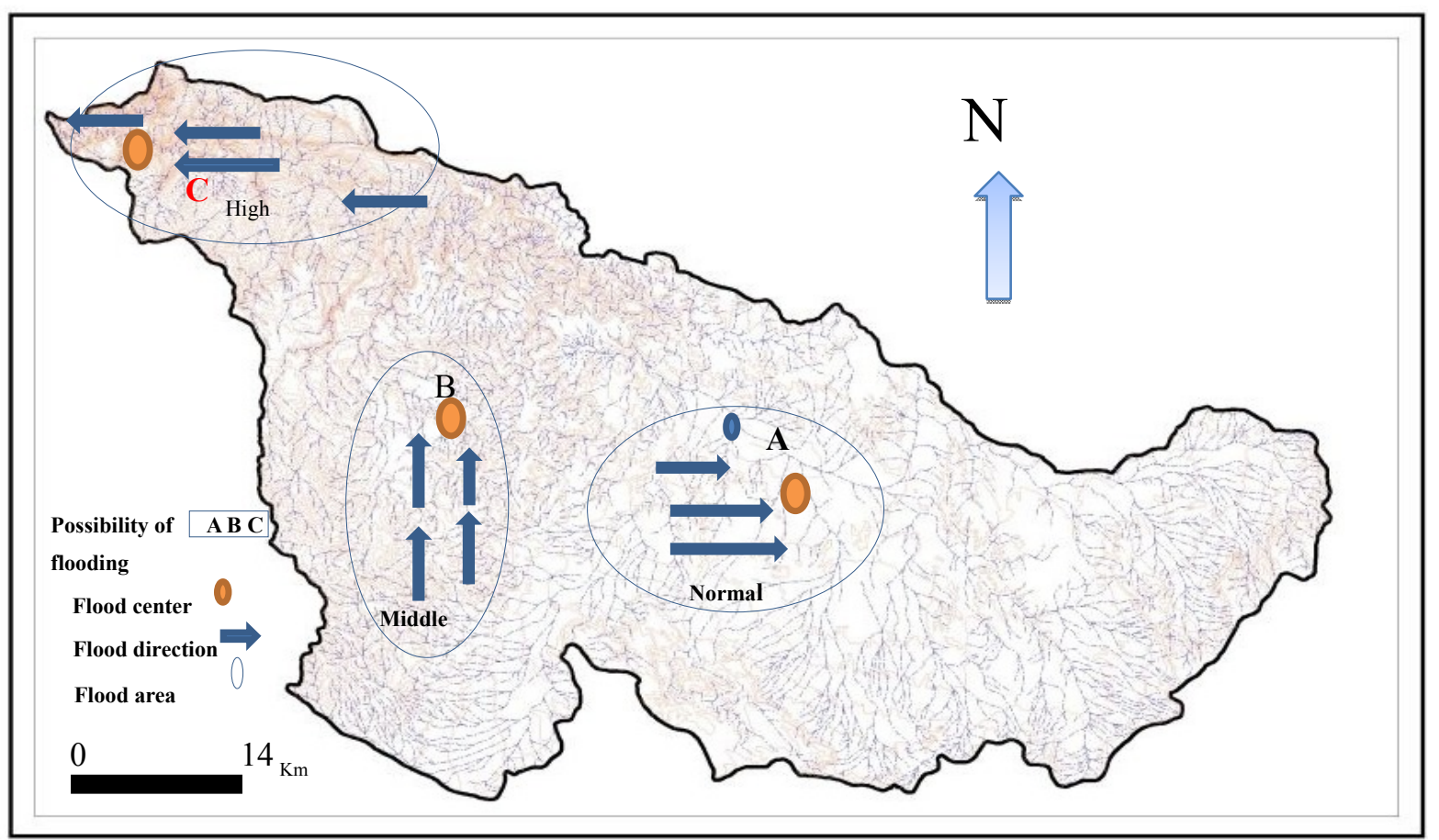

Figure 9. The geographical distribution of river flooding in the basin of Wadi AL-Hasa and the level of probability of occurrence

\section{Conclusion}

The magnitude of stream floods in Wadi Al-Hasa depends on a set of geomorphological variables, the most important of which are the characteristics of rainfall, the basin area and shape, the surface topography, the gradient degree of the Valley, and the morphology of the river channel and its capacity. These variables determine the volume of the water discharge and its speed of flow in the river channels that make up the water network of Wadi Al-Hasa. These variables also make a temporal variation in the speed at which the water flow in the stream flood reaches its peak. 
The characteristics of the water network, including the discharge density and the stream bifurcation, have directly contributed in increasing the water discharge of the Valley. The results indicated the increasing likelihood of frequent flooding in the basins of the sub-reaches of Wadi Al-Hasa with the increase in their stream orders, as a result of the increase in the amount of discharge water. The results of the statistical analysis of the stepwise regression showed the importance of the geomorphological variables (stream order, gradient, width of the river channel, vegetation) in explaining the variation in the volume of the water discharge of the river tributaries in the basin, as these variables interpreted about (53\%) of the total variation. The study also showed that there are three areas with increased likelihood of flooding in the basin, namely: the estuaries of the eastern tributaries in Qa' Al-Jinz area; the areas where western tributaries meet with higher stream orders; and the estuary area of the mainstream of Valley.

\section{References}

Baker, V., \& Pickup, G. (1987). Flood geomorphology of the Katherine Gorge, Northern Territory, Australia. $\begin{array}{llllll}\text { Geological Society of } & \text { America, }\end{array}$ http://dx.doi.org/10.1130/0016-7606(1987)98<635:FGOTKG>2.0.CO;2

Bender, F. (1974). Geology of Jordan. Gebruder, Borntager, Berlin.

Brammer, H. (1990). Floods in Bangladesh: geographical background to the 1987 and 1988 floods. The Geographical Journal, 156, 12-22. http://dx.doi.org/10.2307/635431

Costa, J. (1987). A comparison of the largest rainfall-run off floods in the United States with those of the people's Republic of China and the rest of the world. Hydrology Journal, 96, 101-115. http://dx.doi.org/10.1016/0022-1694(87)90146-6

England, J. F., Godaire, J. E., \& Klinger, R.E., et al. (2010) Paleohydrologic bounds and extreme flood frequency of the Upper Arkansas River, Colorado, USA. Geomorphology, 124, 1-16. http://dx.doi.org/10.1016/j.geomorph.2010.07.021

Foulds, S., Griffith, H., \& Macklin M., et al. (2014). Geomorphological records of extreme floods and their relationship to decadal- scale climate change. Geomorphology, 216, 193-207. http://dx.doi.org/10.1016/j.geomorph.2014.04.003

Harun, R. (1987). Morphologic Instability of Floodways: Assiniboine diversion, Manitpba, Canada. Applied Geography, 7(3), 181-195. http://dx.doi.org/10.1016/0143-6228(87)90032-4

House, P. K., Webb, R. H., \& Paker, et al. (2002). Ancient flood modern hazard; Principles and applications of Pale flood hydrology: Water Resource and Application, American Geophysical union, Washington, 15, 385-390.

Japan International Cooperation Agency (JICA). (1990). Water Resources Study of the Al-Jafr Basin. Ministry of Planning in Association with Water Authority of Jordan. Amman.

Jarrett, R. D. (1999). Flood hydrology of foothill and mountain streams in Colorado, Ph.D. Earth and Planetary Science Letters, 171, 267-276.

Jennifer, B., \& Brain, F. (2002).Observation on mass media reporting and individual motivation to obtain a flood inundation map River Torrens, Adelaide, south Australia. Applied Geography, 2(2), 143-153.

Leopold, L. B., Wolman, M. G., \& Miller, J. P. (1964). Fluvial Process in Geomorphology, W. H. Freeman and Company, San Francisco, 17-50.

Levish, D. R., England, J., \& Klawon, J. E., et al. (2003). Flood hazard analysis for Seminoe and Glendo Dams, Kendrick and North Platte project, Wyoming final Report. Bureau of Reclamation. Denver, 120.

Minea, G., \& Zhaharia, L. (2011). Geomorphological impact of floods in the Basca catchment (Romania). Revista de Geomorfologie, 13, 67- 74.

Ministry of Agriculture. (1993). National soil map and land use project. The Soil of Jordan, 1(3).

Moussa, R., Voltz, M., \&Andrieux, P. (2002). Effects of the spatial organization of agricultural management on the hydrological behavior of a farmed catchments during flood events. Hydrological Processes, 16, 393-412. http://dx.doi.org/10.1002/hyp.333

Patterson, J. L. (1964). Magnitude and frequency of floods in the United States - Part 7, Lower Mississippi river basin ,US, Geological Survey - Supply Paper 1681-636.

Patton, P. C., Baker, V. R., \& Kochel, R. C. (1979). Slack water deposits; a geomorphic paleohydrology In: 
Rhoders, D. D., Williams, G.P (Eds). Adjustments of the fluvial system, Kendall/ Hunt publishing Dubuque, IA, 225-253.

Royal Jordanian Geographic Centre. (2008) Topographic Maps of the area Hasa and Tafila (1 -50,000), Amman, Jordan.

Salama, H. (1980).Geomorphological Analysis of the Morphometric Characteristics Of basins in Jordan. Journal of Drasat, 1, 32-50.

Sami, K., Mohsen, B. A., \& Afef K, et al. (2013). Hydrological modeling using GIS for Mapping flood zones and degree flood risk in Zeuss -Koutine (South of Tunisia). Journal of Environmental Protection, 4(12), 1404-1422. http://dx.doi.org/10.4236/jep.2013.412161

Schick, A. (1971). A desert Flood: Physical Characteristics Effects Study of the Southern Araba Watershed. Jerusalem Study in Geography, 2, 155.

Smith, J. A. (1989). Regional flood frequency analysis using extreme order statistics of the annual peak record. Water Resources, 25(2), 311-317. http://dx.doi.org/10.1029/WR025i002p00311

Sullivan, A., Ternan , L., \& Williams, E. (2004). Land Use Change and Hydrological Response in the Camel Catchment, Cornwall. Applied Geography, 24(2), 119-137. http://dx.doi.org/10.1016/j.apgeog.2003.11.002

Verstraeten, G., \& Poeson, J. (2001). Factors controlling sediment yield from small intensively cultivated catchments in a temperate humid climatic. Geomorphology, 40, $123-144$. http://dx.doi.org/10.1016/S0169-555X(01)00040-X

Woube, M. (1999). Flooding and Sustainable Land - Water Management in the Lower Baro - Akoba River Basin, Ethiopia. Applied Geography, 17(3), 235 - 251. http://dx.doi.org/10.1016/S0143-6228(99)00004-1

\section{Copyrights}

Copyright for this article is retained by the author(s), with first publication rights granted to the journal.

This is an open-access article distributed under the terms and conditions of the Creative Commons Attribution license (http://creativecommons.org/licenses/by/3.0/). 